\title{
Effect of powdered extract of peppermint (Mentha piperita) on adult cowpea bruchid (Callosobruchus maculatus) mortality during storage in Jos - Plateau
}

\author{
Amazu O. B. ${ }^{1}$, Nwadike C. ${ }^{{ }^{\star}}$, Ishaya M. ${ }^{1}$, Oladejo O. A. ${ }^{1}$, Walter J. C. ${ }^{1}$, Anayip Mudi ${ }^{3}$, \\ Shakirdeen M. O. ${ }^{3}$ and Mmadu D. U. ${ }^{2}$ \\ ${ }^{1}$ Department of Pests Management Technology, Federal College of Forestry-Forestry Research Institute of Nigeria, P. \\ M. B. 2019, Bauchi Road, Jos - Nigeria. \\ ${ }^{2}$ Department of Agricultural Technology, Federal College of Forestry-Forestry Research Institute of Nigeria, P. M. B. \\ 2019, Bauchi Road, Jos - Nigeria. \\ ${ }^{3}$ Department of Crop Production, Federal College of Forestry-Forestry Research Institute of Nigeria, P. M. B. 2019, \\ Bauchi Road, Jos - Nigeria.
}

*Corresponding author. Email: chrisnwadike1@gmail.com/chrisnwadike@fcfjos.edu.ng; Tel: +234 8035369835.

Copyright (@) 2021 Amazu et al. This article remains permanently open access under the terms of the Creative Commons Attribution License 4.0, which permits unrestricted use, distribution, and reproduction in any medium, provided the original work is properly cited.

Received 5th January, 2021; Accepted 8th February, 2021

\begin{abstract}
The over dependence and continues use of synthetic insecticides to control storage pests have been associated with several demerits. This study was conducted to evaluate the insecticidal effect of peppermint (Mentha piperita) leaf powder on Callosobruchus maculatus. The peppermint plant was sourced locally and the C. maculatus were cultured to obtain the adult Bruchids. The peppermint was washed, dried under ambient temperature and pulverized. Complete Randomized Design was adopted for this trial with three replications of six treatment dosages of 2.5, 5.0, 7.5, $10.0,12.5$ and $0.0 \mathrm{~g}$ respectively of the plant material. The trial lasted for four weeks. High Bruchids mortality was observed after treatment with Mentha piperita leaf powder extract. Phytochemical screening of the test plant revealed presence of flavonoids, tannins, saponins, carbohydrates and cardiac glycosides. Descriptive statistic and analysis of variance (ANOVA) were used to analyze the data. Means $(p \leq 0.05)$ were separated using Duncan Multiple Range Test (DMRT). Dosage rate and mean mortality values at the various doses were statistically significant after 48,72 and 96 hours. The mortality could be attributed to high presence flavonoid in the Mentha piperita leaf powder. The results suggest that the leaf of peppermint has insecticidal property against adult C. maculatus. However, further trials are required to investigate effective dosage rates for other stored grains and to isolate and characterize the active flavonoids contained in the plant.
\end{abstract}

Keywords: Bruchid, cowpea, Mentha piperita, mortality, phytochemicals, storage pests.

\section{INTRODUCTION}

Cowpea (Vigna unguiculata (L) Walp) is an important legume in many developing countries. It is grown mainly for its grains as a major source of vegetable protein in subSaharan Africa where it constitutes an important part of the local diet, culture and economy (Olakojo et al., 2007; Deshpande et al., 2011; Lephale et al., 2012). The seed is regarded as a completely balanced food that feeds millions of people in developing worlds with an annual world-wide production estimated around 4.5 metric tons on 12 to 14 million hectares (Diouf, 2011). According to IITA (2001), it was reported that Nigeria is the world leading producer of cowpea, producing about 272,672 metric tons annually.

Cowpea production in the country is faced with a wide range of biotic and abiotic constraints (Singh, 2005). In storage, Callosobruchus maculatus, is regarded as the most important and common pest of cowpea both in Africa 
and Asia (Jackai and Daoust, 1986; Deshpande et al., 2011). Estimates of 4 to $90 \%$ losses have been reported (IITA, 1989; Umeozor, 2005; Udo and Harry, 2013) due to perforations from newly hatched larvae which bore into the cowpea grains. Holes left in the seeds by the emerging adults, reduces the degree of usefulness and making the seeds unfit either for planting or human consumption (IITA, 1989). The initial infestation starts on the field and extends to the store.

Some synthetic insecticides available for the control of this key pest are Actellic (2\%) or Actellic super and Phostoxin gas are very helpful to the farmer, but they are expensive and may not be available everywhere. Also, Phostoxin is a fumigant that can kill humans and animals (Joana and Gungula, 2010) and requiring training for their efficient use such that many cowpea growers cannot afford them, also farmers are not taught on how to apply them properly; they pose a health risk to the human population, killing of non-target species and destruction of natural enemies. Synthetic insecticides can cause pests resistance, resurgence and, development of resistance by insects etc. In the light of the above, alternative control consideration could be sourced from indigenous preservatives locked in plants as bio constituents (Yusuf et al., 2006; Mundi et al., 2012; Bamaiyi et al., 2006). Studies have shown that Green plants act as a reservoir for inexhaustible source of innocuous pesticides, which are non-toxic to mammals and easily biodegradable than synthetic chemicals (Joana and Gungula, 2010). Phytochemical constituents like anthraglycosides, phlobatanin, tannins, flavonoids, alkaloids, saponins, coumarins, phenols, carboxylic acids, terpenes etc., have conferred specific characteristics and properties to plants which could be exploited for use as insect pests antifeedant or repellents (Trease and Evans, 1989; Lee et al., 2003; Kumar et al., 2013)).

The peppermint plant (M. piperita, Lamiaceae) also known as Mentha balsamea Wild has been reported to be native to Europe, midle east but currently cultivated in different parts of the world (Behnam et al., 2006). The Leaves of peppermint are used as condiment in some food dishes and as flavoring for ice creams and liqueurs. Its essential oils and extracts of $M$. piperita leaves have been used as medicine to treat inflammation of the oral mucosa, cold, musculoskeletal pain, gastrointestinal and respiratory diseases (Mckay et al., 2006). The presence of secondary metabolites in its essential oils such as monoterpenoids and phenolic compounds have conferred this much desired ethnobotanical significance (Mimica-Dukic and Bozin, 2008). Diniz do Nascimento et al. (2020), reported that the chemical composition of peppermint essential oils may varies due to extraction method, environmental conditions, and geographical origin, but, in general, it contains as the major constituents: menthol, epoxyocimene, linalool, menthone, eucalyptol, and neomenthol.

There are many high plant species in Nigeria whose phytochemical constituent potentials are still unexploited. However, this preliminary study was carried out to evaluate, amongst other objectives, the insecticidal efficacy of powdered of Mentha piperita in the control of the bruchid (Callosobruchus maculatus (L) Walp) attacking cowpea (Vigna unguiculata (L) Walp) seed in storage.

\section{MATERIALS AND METHODS}

\section{Study area}

The study was carried out in the Chemistry Laboratory of the Federal College of Jos, Plateau State, $\left(09^{\circ} .56^{\prime} \mathrm{N}\right.$; $08^{\circ} .53^{\prime} \mathrm{E}$ at an altitude of $1,217 \mathrm{~m}$ ), in the Northern Guinea Savanna agro-ecological zone of Nigeria (Kowal and Knabe, 1972).

\section{Insect culture}

Infested cowpea seeds were purchased from Katako market in Jos, Plateau State. About $500 \mathrm{~g}$ of the infested cowpea seeds were weighed. The infested seeds containing the eggs was separated and put in a container. The containers used in rearing the insects were plastic containers measuring $17 \mathrm{~cm}$ and $17 \mathrm{~cm}$ diameter and depth, respectively. Each container was covered with 10 $\mathrm{mm}$ mesh sieve to allow free air circulation and also to prevent insects from escaping (Habib et al., 2013). This was carried out at ambient temperature of $28^{\circ} \mathrm{C}( \pm 2)$ and relative humidity of between $70-75 \%$ for 21 days. The newly emerged bruchids of about 24 hours old were kept for the work.

\section{Collection of plant material}

The plant material Mentha piperita leaves were collected from Chinese garden Jos. The leaves were washed with distilled water and air dried for two weeks. The plant materials were pulverized into powder using a mortar and pestle and sieved to obtain uniform size. The powder was kept in air- tight containers labeled and stored ready to be used for the experiment.

\section{Treatment application}

The plant powder was added to each of the containers containing $100 \mathrm{~g}$ of the cowpea seeds in following dosages: 0.0 (control), 2.5, 5.0, 7.5, 10.0 and12.5 g. The cowpea grains and the plant powder were thoroughly mixed with the aid of glass rod and agitated for 5 to 10 minutes. Ten freshly emerged bruchids of about 24 hours' old were introduced into each of the treatment. The containers were then arranged in the laboratory bench in a completely randomized design (CRD). All the treatments 
were replicated three times. Mortality count was taken after 24, 48, 72 and 96 hours respectively. Mortality of adult bruchids was obtained by counting the number of dead bruchids in each of the translucent plastic after application of treatment and dead bruchids were removed after every count to avoid double-counting. The data were recorded after 24, 48, 72 and 96 hours according to Asawalam and Arukwe, (2004) and Jembere et al. (1995).

\section{Data analyses}

Data collected were analyzed using (ANOVA) to test for level of significance $(p \leq 0.05)$ on the effects of different dosages of the plant and mean separation was carried out using Duncan Multiple Range Test (DMRT).

\section{Extraction methods of the plant material}

$100 \mathrm{~g}$ of the pulverized leaves of peppermint was percolated in $200 \mathrm{ml}$ of distilled water for 24 hours. The content was filtered using Whatman No1 filter paper and the filtrate was then concentrated on a bath to obtain the aqueous crude extract.

\section{Phytochemical analysis}

The determination of the bioactive constituents responsible for the insecticidal activity of peppermint (Mentha piperita) was carried out using the method described by Rao et al. (2016). Qualitative phytochemical screening of alkaloids, tannins, saponins, flavonoids, carbohydrates, steroids, anthraquinones and cardiac glycosides were used for the analyses.

\section{Test for alkaloids}

About $2 \mathrm{ml}$ of the aqueous extract of the plant sample was carefully measured into a test tube and $2 \mathrm{ml}$ of Mayer's reagent (potassium-mercuric iodide) was immediately added. The appearance of a yellow colour precipitate confirmed the presence of alkaloids.

\section{Test for tannins}

About $2 \mathrm{ml}$ of the aqueous plant extract was added into 2 $\mathrm{ml}$ solution of $10 \%$ ferric chloride in a test tube. The observation of the presence of blue-black or greenish black precipitate confirmed the presence of tannins in the plant sample.

\section{Test for flavonoids}

About $1 \mathrm{ml}$ of the extract was pipetted and added to $1 \mathrm{ml}$ of $2 \mathrm{~N}$ sodium hydroxide solution in a test tube. The appearance of yellow or orange colour indicated the presence of flavonoids in the sample.

\section{Test for saponins}

About $2 \mathrm{ml}$ of the aqueous extract of the plant sample was added to $2 \mathrm{ml}$ of distilled water in a graduated measuring cylinder. The content was then vigorously mixed by shaking. The formation of $1 \mathrm{~cm}$ layer of foam in the glass ware confirmed the presence of saponins.

\section{Test for carbohydrates}

To $2 \mathrm{ml}$ of the extract sample, few drops of Molisch's reagent was added, followed by the addition of $1 \mathrm{ml}$ of concentrated $\mathrm{H}_{2} \mathrm{SO}_{4}$ to the side of the test tube. The mixture was then allowed to stand for 2 minutes after which $5 \mathrm{ml}$ of distilled water was added. The formation of red or dull violet colour between the two layers indicated the presence of carbohydrate in the sample.

\section{Liebermann-Burchard test for steroids}

About $2 \mathrm{ml}$ of the extract was added to $2 \mathrm{ml}$ acetic anhydride in a test tube, after which few drops of concentrated sulphuric acid was added. The presence of blue-green ring confirmed the presence of steroids.

\section{Test for anthraquinones}

$2 \mathrm{ml}$ of the plant extract was added to $2 \mathrm{ml}$ of dilute tetraoxosulphate (IV) acid. The content was placed in a water bath and then filtered. To the cold filtrate, equal amount of chloroform or benzene was added. The organic layer of benzene was then removed after which $5 \mathrm{ml}$ of ammonia was added. The formation of red, pink or violet colour in the ammoniacal lower layer indicated the presence of anthraquinones.

\section{Test for cardiac glycosides}

A few drops of glacial acetic acid were added to $2 \mathrm{ml}$ of the aqueous extract. Drops of $10 \%$ ferric chloride and then concentrated tetraoxosulphate (IV) acid were then added. The formation of reddish brown colouration between the two layers showed the presence of cardiac glycosides.

\section{RESULTS}

\section{Phytochemical screening}

The results of the phytochemical screening of the powdered leaf extract of Mentha piperita leaves as presented in Table 1 indicated the presences of useful 
Table 1. Phytochemical components of Mentha piperita leaf powder.

\begin{tabular}{lc}
\hline Phytochemical & Mentha piperita \\
\hline Alkaloids & - \\
Tannins & ++ \\
Flavonoids & +++ \\
Saponins & + \\
Carbohydrates & + \\
Steroids & - \\
Anthraguinones & - \\
Cardiac glycosides & + \\
\hline
\end{tabular}

Note: - Negative $+=$ Mildly present $++=$ =More Moderately present; $+++=$ Highly present.

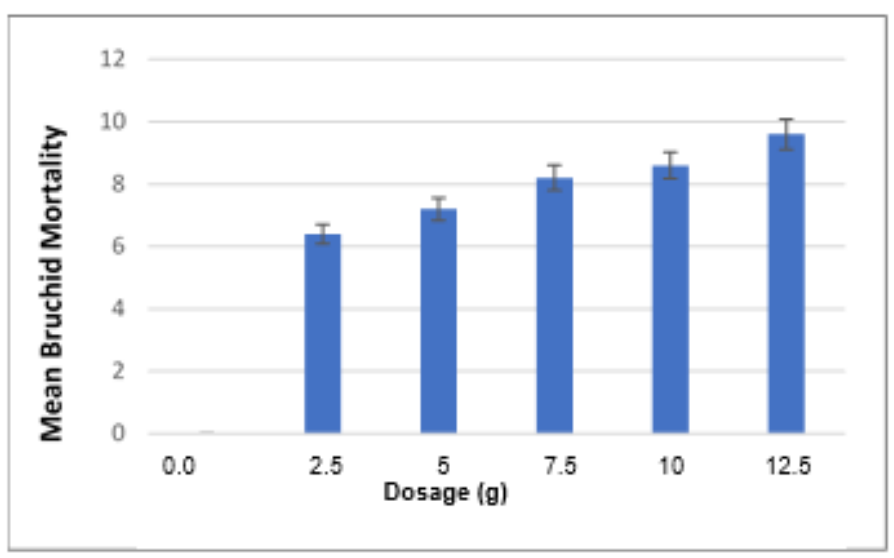

Figure 1. Effect of Mentha piperita powder on bruchid mortalit after 48 hours under different dosages.

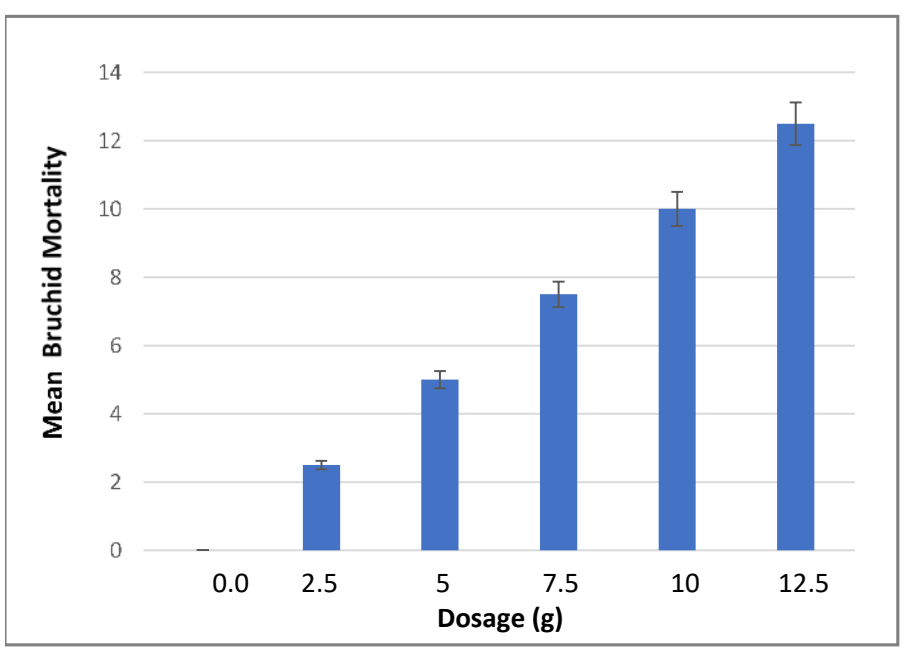

Figure 2. Effect of Mentha piperita powder on bruchid mortality after 72 hours under different dosages.

secondary metabolites in the plant material. Saponins, carbohydrate, cardiac glycosides were slightly present, tannins moderately presence, and high presences of

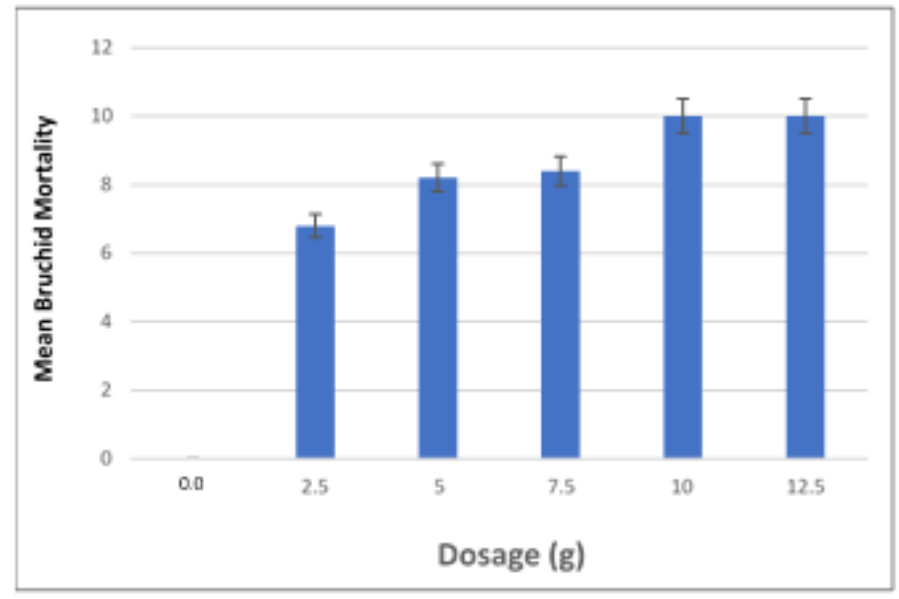

Figure 3. Effect of Mentha piperita powder on bruchid mortality after 96 hours under different dosages.

flavonoids were observed in the study. However, no significant traces of steroids, alkaloids and anthraquinones were detected in the crude plant leaf powdered extract (Table 1).

\section{Mean effect of Mentha piperita powder extracts on Callosobruchus maculates mortality at different times of exposure dosages}

Following the introduction of the treatments, no bruchid mortality were recorded and means were not statistically significant during the 24-hour duration for all dosages ( $\mathrm{F}=$ $0.04, D F=17, P=0.103$ ). Means for bruchid mortality were statistically significant at 48 hours $(F=59.58, D F=17, P$ $=0.000)$, 72hours $(F=10.11, D F=17, P=0.001)$ and 96 hours $(F=2.30, D F=17, P=0.122)$ durations. The mean bruchid mortality with respect to various treatments is presented in Figures 1 to 3, respectively.

\section{DISCUSSIONS}

The phytochemical result of $M$. piperita leaves powder revealed the presence of some bioactive compounds such as saponins, tannins, carbohydrates and cardiac glycosides and flavonoids in varying amounts. The presence of these metabolites in this extract with known insecticidal properties (Rubabura et al., 2014) could be responsible for the mortality of the weevils. Although, this study did not set out to quantify the relative amount of the respective phytochemicals present in the extract or to isolate the compound believed to be responsible for the bruchid mortality. However, the mortality could be due to the presence of limonene present in the flavonoids fraction of the plant material. An independent study carried out by Hebeish et al. (2008) reported that limonene present in flavonoids of Mentha piperita were found responsible for 
the mortality of rice weevil, Sitophilus oryzae. Also, Jang et al. (2005) and Phillip et al. (2010) reported that limonene present in the flavonoids has been used as systemic and contact fumigants with toxicity that can cause up to $100 \%$ mortality in housefly, bruchids, saw-toothed grain beetle and German cockroach. Similarly, Kordali et al. (2006) reported about $100 \%$ mortality of the Colorado potato beetle during their studies as a result of limonene presence in flavonoids. Present mortality suggests diverse mode of action of the extract on the target pests. Results showed increased mortality of weevils with increased quantity of leaf powder extract applied over time. The percentage mortality of Callosobruchus maculatus at 48, 72 and 96 hours showed a direct proportionality to applied dosages and time of exposure. The present study also agrees with Aniszewski (2007), who reported that some toxic secondary metabolites which can block inhibit enzymes activities, ionic channels, interfere with neurotransmission, loss of coordination, and death.

\section{Conclusion and Recommendation}

Data from this study indicate that mint plant leaf powder has potential for the preservation of cowpea seeds against C. mucalatus. The study recommends that the leaf powder of peppermint could be used as an alternative control against adult $C$. maculatus during storage of cowpea seeds at $0.0125 \mathrm{~kg}$ powder of peppermint to $0.1 \mathrm{~kg}$ seeds. Also, further studies should be carried out to investigate effective dosage rates of the test plant extract for other stored agricultural grains.

\section{CONFLICT OF INTEREST}

The authors declare that they have no conflict of interest

\section{REFERENCES}

Aniszewski, T. (2007). Aklaloid Chemistry, biological significance, applications and ecological role. 1st Edition, Elsevier Science. p. 334.

Asawalam, E. F., \& Arukwe, E. U. (2004). Effect of combination of some plant powders for the control cowpea bruchids (Callosobruchus maculatus). Nigerian Agricultural Journal, 35, 75-86.

Bamaiyi, L. J., Ndams, I. S., Toro, W. A., \& Odekina, S. (2006). Effect of mahogany Khaya senegalensis seed oil in the control of Callosobruchus maculatus on stored cowpea. Plant Protection Science, 42(4), 130-134.

Behnam, S., Farzaneh, M., Ahmadzadeh, M., \& Tehrani, A. S. (2006). Composition and antifungal activity of essential oils of Mentha piperita and Lavendula angustifolia on post-harvest phytopathogens. Communications in agricultural and applied biological sciences, 71(3 Pt B), 1321-1326.

Deshpande, V. K., Makanur, B., Deshpande, S. K., Adiger, S., \& Salimath, P. M. (2011). Quantitative and qualitative losses caused by Callosobruchus maculatus in cowpea during seed storage. Plant Archives, 11(2), 723-731.
Diniz do Nascimento, L., Moraes, A. A. B. D., Costa, K. S. D., Pereira Galúcio, J. M., Taube, P. S., Costa, C. M. L., Neves Cruz, J., de Aguiar Andrade, E. H., \& Faria, L. J. G. D. (2020). Bioactive natural compounds and antioxidant activity of essential oils from spice plants: New findings and potential applications. Biomolecules, 10(7), 988.

Diouf, D. (2011). Recent advances in cowpea [Vigna unguiculata (L.) Walp.] "omics" research for genetic improvement. African Journal of Biotechnology, 10(15), 2803-2810.

Habib, L. I., Nwadike, C \& Ahmed, B. I. (2013). Evaluation of selected botanicals on oviposition, adult emergence and mortality of Callosobruchus maculatus (F.) on stored cowpea grains in Jos, Nigeria. Journal of Environment, Technology and Sustainable Agriculture, 1 (1), 72-81.

Hebeish, A., Fouda, M. M. G., Hamdy, I. A., EL- Sawy, S. M. \& Abdel- Mohdy, F. A., (2008). Preparation of durable insect repellant cotton fabric: Limonene as insecticide. Carbohydrate Polymers 74(2), 268-273.

IITA (1989), Research Brief, Vol.9. International Institute of Tropical Agriculture, Ibadan, Nigeria. p. 302

IITA (2001). Breeding of Multiple disease resistance in cowpea. Annual Report and Research Highlight. International Institute for Tropical Agriculture Ibadan, Nigeria. p. 97.

Jackai, L.E.N. \& Daoust, R.A. (1986). Insect pests of cowpea, Annual Review of Entomology, 31, 95-119.

Jang, Y. S., Yang, Y. C., Choi, D. S., \& Ahn, Y. J. (2005). Vapor phase toxicity to marjoram oil compounds and their related monoterpenoids to Blattella germanica (dictyoptera: Blattellidae). Journal of Agricultural and Food Chemistry, 50(20),7892-7898.

Jembere, B., Obeng-Ofori, D., Hassanali, A., \& Nyamasyo, G. N. N. (1995). Products derived from the leaves of Ocimum kilimandscharicum (Labiatae) as post-harvest grain protectants against the infestation of three major stored product insect pests. Bulletin of Entomological Research, 85(3), 361-367.

Joana, O. Ilesanmi and Daniel T. Gungula (2010). Preservation of cowpea (Vigna unguiculata (L.) Walp) grains against cowpea bruchids (Callosobruchus maculatus) using neem and moringa seed oils. International Journal of Agronomy, Volume 2010, Article ID 235280, 8 pages.

Kordali, S., Aslan, I., Calmasur, O \& Cakir, A. (2006). Toxicity of essential oils isolated from three Artemisia species and some of their major components to granary weevil, Sitophilus granaries (L.) (Coleoptera: Curculionoide). Industral Crops and Products, (provide the volume and issue number), 162-170.

Kowal, J. M., \& Knabe, D. T. (1972). An Agroclimatological atlas of the Northern States of Nigeria Ahmadu Bello University Press Zaria.

Kumar, M. S., Rao, M. R. K., Jha, N. K., \& Ranjan, P. (2013). Comparative study on phytochemicals from leaves of Mentha piperita (Mint), Psidium guajava (Guava) and Moringa oleifera (Drumstick). Journal of Pharmacy Research, 1(2), 223-226.

Lee, S., Peterson, C. J., \& Coats, J. R. (2003). Fumigation toxicity of monoterpenoids to several stored product insects. Journal of Stored Products Research, 39(1), 77-85.

Lephale, S., Addo-Bediako, A., \& Ayodele, V. (2012). Susceptibility of seven cowpea cultivars (Vigna unguiculatus) to cowpea beetle (Callosobruchus maculatus). Agricultural Science Research Journal, 2(2), 65-69.

McKay, D. L., \& Blumberg, J. B. (2006). A review of the bioactivity and potential health benefits of peppermint tea (Mentha piperita L.). Phytotherapy Research: An International Journal Devoted to Pharmacological and Toxicological Evaluation of 
Natural Product Derivatives, 20(8), 619-633.

Mimica-Dukic, N., \& Bozin, B. (2008). Mentha L. species (Lamiaceae) as promising sources of bioactive secondary metabolites. Current Pharmaceutical Design, 14(29), 31413150.

Mundi, A. D., Adamu, R. S., Ajayi, F. A., Bamayi, L. J., \& Egwurube, E. A. (2012). Insecticidal evaluation of some botanical leaf powders on cowpea beetle Callosobruchus maculatus (F.) on stored bambara groundnut (Vigna subterranea (L.) Verdcourt. Production Agriculture and Technology Journal (PAT), 8(1), 52-65.

Olakojo, S. A., Ayanwole, J. A., \& Obasemola, V. I. (2007). Laboratory screening of seeds of some cowpea cultivars (Vigna unguiculata) for tolerance to cowpea beetles (Callosobruchus maculatus) in a hot humid environment, American-Eurasian Journal of Agricultural and Environmental Science 2(5), 528-533.

Phillip, A. K., Appel, A. G., \& Sims, S. R. (2010). Tropical toxicity of essential oil to the German cockroach (Dictyoptera: Blattellidae). Journal of Economic Entomology, 103(2), 448459.

Rao, M. U., Abdurrazak, M., \& Khamsah, S. M. (2016). Phytochemical screening, total flavonoid and phenolic content assays of various solvent extracts of tepal of Musa paradisiaca. Malaysian Journal of Analytical Sciences, 20(5), 1181-1190.

Rubabura, K., Nsambu, M., Muhigwa, B., Bagalwa, M., \& Bashwira, S. (2014). Evaluation in vitro activity of insect alkaloid, saponins, terpenoids or steroids extracts Capscicum frutescens L. (Solanaceae) against Antestiopsis orbitalis ghesquierei, pests of coffee trees. International Journal of Innovation and Applied Studies, 8, 1231-1243.
Singh, B. B. (2005). Cowpea [Vigna unguiculata (L.) Walp]. In: Singh, R. J., Jauhar, P. P. (eds.). Genetic resources, chromosome engineering and crop improvement, vol 1.CRC Press, Boca Raton. Pp. 117-162.

Trease, G. E., \& Evans, W. C. (1989). Trease and Evan's Textbook of Pharmacognosy. 13th Edition. Cambridge University Press, London. p. 546.

Udo, I. O., \& Harry, G. I. (2013). Effect of groundnut oil in protecting stored cowpea (Vigna unguiculata) from attack by cowpea weevil (Callosobruchus maculatus), 3(1), 89-92.

Umeozor, O. C. (2005). Effect of the infection of Callosobruchus maculatus (Fab.) on the weight loss of stored cowpea (Vigna unguiculata (L.) Walp). Journal of Applied Science and Environmental Management, 9(1), 169-172.

Yusuf, S. R., Bununu, U. A., \& Mohammed, A. (2006). The use of abuse of insecticide by farmers in the management of insect pests of cowpea in Tafawa Balewa Local Government Area, Bauchi State. In: Adepoju, S. O., \& Okuneye, P. B. (eds). Proceedings of 20th Annual National Conference of Farm Management Association of Nigeria. Held at the Federal College of Forestry, Jos, 18th - 21st September, 2006. 